REPORTS OF MORPHOLOGY
Official Journal of the Scientific Society of Anatomists,
Histologists, Embryologists and Topographic Anatomists
of Ukraine
journal homepage: https://morphology-journal.com

\title{
Correlations of time indicators of thigh rheogram with anthropometric dimensions in volleyball players of different \\ somatotypes
}

Khavtur V.O. ${ }^{1}$, Fedoniuk L.Ia. ${ }^{1}$, Sarafyniuk L.A. ${ }^{2}$, Shapoval O.M. ${ }^{2}$, Smolko N.M. ${ }^{2}$

${ }^{1}$ SHEI "I.Ya. Horbachevsky Ternopil State Medical University of the Ministry of Health of Ukraine", Ternopil, Ukraine ${ }^{2}$ National Pirogov Memorial Medical University, Vinnytsya, Ukraine

\section{ARTICLE INFO}

Received: 27 December, 2019

Accepted: 5 February, 2020

UDC: $572.087: 612.13: 796.071$

CORRESPONDING AUTHOR

e-mail: khavtur@tdmu.edu.ua Khavtur V.O.

\begin{abstract}
The constitutional features of the organism are an essential lever of sports performance, because they affect the general and special physical performance, aerobic productivity and efficiency of energy supply systems, in particular the indicators of central and peripheral hemodynamics. The aim of the study was to establish the features of the relationships between the temporal parameters of the rheovasogram of the thigh and anthropometric indices in highly qualified young women volleyball players, who belong to different constitutional types. An anthropo-somatotypological study of 113 high-level volleyball players of youth age (from 16 to 20 years old) was conducted. Anthropometric research was carried out by the method of V.V. Bunak (1941), somatotypological - by the calculated modification of the method of Heath-Carter (1990). According to the results of somatotyping, it was found that 29 volleyball players belonged to the mesomorphic type of constitution, to the ectomorphic type - 26 volleyball players, to the ecto-mesomorphic type - 27 volleyball players, to the middle intermediate type -26 volleyball players, to endo-mesomorphic type - only 5 people. Rheovasographic parameters of the thigh were determined using tetrapolar rheocardiography on a computer diagnostic complex. Estimation of temporal rheovasographic parameters was performed according to the method of Ronkin and Ivanov [1997]. The analysis of the obtained results was performed in the licensed program "Statistica 5.5" using Spearman's correlation analysis. We found that in volleyball players of mesomorphs with indicators of external body structure, the temporal parameters of the thigh rheovasogram had few reliable mostly medium strength, direct correlations, except for the time of the ascending part of the rheogram and slow blood supply. In volleyball players of ectomorphic somatotype, the established relationships indicate that with increasing diameters of the pelvis and girth of the forearm, crus, thighs, there will be an elongation of the time parameters of the rheovasogram of the thigh. Volleyball players with an ecto-mesomorphic somatotype of the body showed a fairly large number of reliable inverse correlations, the thickness of the skin and fat folds is inversely proportional to the most time parameters of the thigh rheovasogram, except for the time of slow blood supply. Volleyball players of the intermediate somatotype, compared with other observation groups, found the most numerous relationships between anthropometric size and time indicators of the rheovasogram.

Keywords: correlation, temporal indicators of thigh rheovasogram, anthropometry, somatotype, volleyball players.
\end{abstract}

\section{Introduction}

Constitutional features of the organism, which are severely affected by genetic factors, in turn, are a significant lever of sports performance [8, 15, 23, 26]. Somatometric and somatotypological characteristics affect the efficiency of energy supply systems, development of physical qualities, general and special physical performance and

aerobic performance, intensity and duration of recovery processes, the nature of adaptation processes, resistance to various exogenous factors $[6,16]$. A factor that does not cause objections to athletic performance is the functional state of the athlete's cardiovascular system [1, 9, 18, 22]. Many scientific studies have proven the importance of 
indicators of central and peripheral hemodynamics for increasing the level of fitness of athletes and the formation of a high level of adaptive potential to intense physical activity in different directions [4, 10]. In turn, morpho-functional indicators of the cardiovascular system are under strict control of the constitutional features of the organism. Scientists have established relationships between indicators of external body structure and hemodynamic parameters [21, 24, 25]. In recent years, the work is devoted to establishing such relationships and interdependencies in athletes of different sports [7, 11, 12, 26].

The aim of our work is to establish the features of the relationships between the temporal parameters of the rheovasogram of the thigh and anthropometric indices in highly qualified young women volleyball players, who belong to different constitutional types.

\section{Materials and methods}

On the basis of the research center of National Pirogov Memorial Medical University, Vinnytsya conducted a study of 113 high-level young women volleyball players (from 16 to 20 years). Sports experience in all cases was more than 3 years.

Anthropometry was performed by the method of V.V. Bunak [2], somatotypological study - by the calculated modification of the method of Heath-Carter [3]. After somatotyping, it was found that 29 volleyball players belonged to the mesomorphic type of constitution, to the ectomorphic type - 26 volleyball players, to the ectomesomorphic type - 27 volleyball players, to the middle intermediate type - 26 volleyball players, to the endomosomorphic type - only 5 people, so we did not perform correlation analysis for it. Rheovasographic parameters of the thigh were determined using tetrapolar rheocardiography on a computer diagnostic complex. Evaluation of temporal rheovasographic parameters was performed according to the method of Ronkin and Ivanov [17].

The analysis of the obtained results was performed in the licensed program "Statistica 5.5" using Spearman's correlation analysis.

\section{Results}

After correlating the temporal rheovasographic parameters determined on the thigh with the dimensions that characterize the physique of the body, in the group of volleyball players with mesomorphic type of constitution, we found not numerous, mostly medium-strength direct connections (Table 1). In particular, the duration of the rheographic wave had significant correlations only with the girth of the neck and the thickness of the skin and fat folds on the crus. The time of ascending thigh rheovasogram part significantly correlated with the width of the distal epiphyses of the thigh and crus, with the circumferential dimensions of the shoulder in the unstressed state, forearms in the upper and lower parts, thighs, neck, crus in the upper and lower parts, with transverse lower thoracic diameter and intertrochanteric distance. We determined that the time of the descending part of the thigh rheovasogram had reliable connections only with the thickness of the skin and fat folds on the abdomen, crus and under the shoulder blade. The time of rapid blood supply is statistically significantly correlated with chest girth on exhalation and at rest, with sagittal mid-thoracic and acromial diameters, with the thickness of the folds on the forearm. It was found that the time of slow blood supply of the rheovasogram of the thigh in mesomorphic somatotype volleyball players had significant correlations with body length, height of the suprathoracic, pubic and acromial points, width of the distal epiphyses of the thigh and crus, circumferential size of the shoulder in relaxed state, forearms at the bottom, thighs, neck, hands and feet, the size of the outer conjugate (see Table 1).

In ectomorphic somatotype volleyball players, the duration of the rheographic wave on the thigh was significantly correlated with body weight, acetabular point height, forearm and crus circumferences in the upper parts, and external conjugate (Table 2). In this group of athletes, the time of the ascending thigh rheovasogram had statistically significant relationships with thigh girth, intercristal and interspinous distances, thickness of skin and fat folds on the back of the shoulder, chest, abdomen, side and crus. The time of the descending part of the rheovasogram had significant correlations with the girths of the forearms and crus in the upper parts and the sagittal mid-thoracic diameter. The time of rapid blood supply of the rheovasogram of the thigh in ectomorph volleyball players had significant correlations with the girth of the foot, intercristal and interspinous distances. The time of slow blood supply to the rheovasogram was significantly correlated with the external conjugate and the thickness of the folds on the abdomen and crus.

In the group of volleyball players with ecto-mesomorphic somatotype (Table 3), significant correlations were found between the duration of the rheographic wave on the thigh and the girth of the crus, the transverse mid-chest diameter and the thickness of the skin and fat folds on the abdomen. The time of the ascending thigh rheovasogram had statistically significant correlations with the width of the distal epiphyses of the shoulder and thigh, the girth of the thighs, crus in the upper and lower parts, the thickness of the skin and fat folds on the abdomen and sides. The time of the descending part of the rheovasogram was significantly correlated only with the thickness of the folds on the abdomen. There are statistically significant relationships between the time of rapid blood supply of thigh vessels and weight, length, body surface area, acromial point height, width of the distal epiphyses of the shoulder and thigh, shoulder girth in a tense state, thighs, crus in the upper and lower parts, thighs, chest, the thickness of the folds on the chest, abdomen, sides. Rheovasographic index time of slow blood supply was 
Khavtur V.O., Fedoniuk L.Ia., Sarafyniuk L.A., Shapoval O.M., Smolko N.M.

Table 1. Values of correlation coefficients $(r)$ of time indicators of rheovasogram of a thigh with anthropometric sizes at mesomorphs young women volleyball players.

\begin{tabular}{|c|c|c|c|c|c|}
\hline \multirow{2}{*}{ Anthropometric indicators } & \multicolumn{5}{|c|}{ Rheovasographic indicators } \\
\hline & C & A & B & A1 & $\mathrm{A} 2$ \\
\hline body weight $(\mathrm{kg})$ & 0.05 & 0.37 & -0.04 & 0.26 & 0.32 \\
\hline body length $(\mathrm{cm})$ & -0.02 & 0.24 & -0.05 & -0.12 & 0.44 \\
\hline body surface area $\left(\mathrm{m}^{2}\right)$ & 0.05 & 0.35 & -0.03 & 0.18 & 0.35 \\
\hline height of the suprathoracic point $(\mathrm{cm})$ & -0.02 & 0.33 & -0.09 & -0.05 & 0.49 \\
\hline pubic point height $(\mathrm{cm})$ & -0.07 & 0.26 & -0.12 & -0.17 & 0.49 \\
\hline height of the acromial point $(\mathrm{cm})$ & -0.03 & 0.35 & -0.11 & -0.03 & 0.50 \\
\hline finger point height $(\mathrm{cm})$ & -0.11 & 0.18 & -0.14 & -0.09 & 0.38 \\
\hline acetabulum point height $(\mathrm{cm})$ & -0.03 & 0.00 & 0.03 & -0.35 & 0.26 \\
\hline the width of the distal epiphysis of the shoulder $(\mathrm{cm})$ & 0.10 & 0.19 & 0.17 & -0.17 & 0.33 \\
\hline the width of the epiphysis forearm $(\mathrm{cm})$ & -0.02 & 0.18 & 0.02 & -0.17 & 0.27 \\
\hline the width of the distal epiphysis of the thigh $(\mathrm{cm})$ & 0.17 & 0.46 & -0.01 & -0.03 & 0.65 \\
\hline the width of the distal epiphysis of the crus $(\mathrm{cm})$ & 0.26 & 0.41 & 0.12 & -0.02 & 0.51 \\
\hline shoulder girth in a tense state $(\mathrm{cm})$ & -0.01 & 0.21 & -0.12 & 0.17 & 0.24 \\
\hline shoulder girth in a relaxed state $(\mathrm{cm})$ & 0.02 & 0.41 & -0.18 & 0.29 & 0.40 \\
\hline forearm girth at the top $(\mathrm{cm})$ & 0.04 & 0.40 & -0.12 & 0.30 & 0.38 \\
\hline forearm girth at the bottom $(\mathrm{cm})$ & 0.18 & 0.47 & 0.04 & 0.02 & 0.60 \\
\hline thigh girth $(\mathrm{cm})$ & 0.17 & 0.51 & 0.01 & 0.27 & 0.48 \\
\hline crus girth at the top $(\mathrm{cm})$ & 0.07 & 0.41 & 0.00 & 0.20 & 0.28 \\
\hline crus girth at the bottom $(\mathrm{cm})$ & 0.01 & 0.40 & -0.09 & 0.16 & 0.34 \\
\hline neck circumference $(\mathrm{cm})$ & 0.41 & 0.40 & 0.29 & -0.09 & 0.61 \\
\hline waist circumference $(\mathrm{cm})$ & -0.11 & 0.08 & -0.09 & 0.08 & 0.08 \\
\hline thighs girth $(\mathrm{cm})$ & -0.15 & 0.17 & -0.16 & 0.27 & 0.07 \\
\hline hand girth $(\mathrm{cm})$ & 0.25 & 0.36 & 0.13 & 0.05 & 0.42 \\
\hline foot girth $(\mathrm{cm})$ & 0.10 & 0.23 & 0.13 & -0.32 & 0.41 \\
\hline chest girth on inhalation $(\mathrm{cm})$ & 0.09 & 0.31 & -0.08 & 0.38 & 0.28 \\
\hline chest girth on exhalation $(\mathrm{cm})$ & 0.12 & 0.29 & -0.05 & 0.40 & 0.25 \\
\hline chest girth at rest $(\mathrm{cm})$ & 0.02 & 0.32 & -0.14 & 0.49 & 0.20 \\
\hline transverse mid-thoracic diameter $(\mathrm{cm})$ & 0.02 & 0.34 & -0.02 & 0.38 & 0.24 \\
\hline transverse lower thoracic diameter $(\mathrm{cm})$ & -0.04 & 0.44 & -0.17 & 0.29 & 0.39 \\
\hline sagittal mid-thoracic diameter $(\mathrm{cm})$ & 0.03 & 0.36 & -0.16 & 0.65 & 0.06 \\
\hline acromial diameter $(\mathrm{cm})$ & -0.07 & -0.31 & 0.09 & -0.41 & -0.06 \\
\hline intercristal distance $(\mathrm{cm})$ & -0.19 & 0.25 & -0.25 & 0.18 & 0.23 \\
\hline interspinous distance $(\mathrm{cm})$ & -0.26 & 0.24 & -0.36 & 0.30 & 0.23 \\
\hline intertrochanteric distance $(\mathrm{cm})$ & 0.02 & 0.43 & -0.02 & 0.38 & 0.27 \\
\hline external conjugate $(\mathrm{cm})$ & -0.04 & 0.38 & -0.10 & 0.22 & 0.42 \\
\hline the thickness of the folds on the back of the shoulder $(\mathrm{mm})$ & 0.07 & -0.12 & 0.19 & -0.27 & -0.01 \\
\hline the thickness of the folds on the front surface of the shoulder $(\mathrm{mm})$ & 0.14 & -0.25 & 0.29 & -0.29 & -0.14 \\
\hline the thickness of the folds on the forearm $(\mathrm{mm})$ & 0.11 & -0.27 & 0.31 & -0.46 & -0.10 \\
\hline the thickness of the folds under the shoulder blade $(\mathrm{mm})$ & 0.32 & -0.08 & 0.42 & -0.15 & -0.10 \\
\hline the thickness of the folds on the chest (mm) & 0.02 & -0.22 & 0.38 & -0.27 & -0.17 \\
\hline
\end{tabular}


Correlations of time indicators of thigh rheogram with anthropometric dimensions in volleyball players...

Table 1. (continuation)

\begin{tabular}{|l|c|c|c|c|c|}
\hline \multicolumn{1}{|c}{ Anthropometric indicators } & \multicolumn{5}{c|}{ Rheovasographic indicators } \\
\cline { 2 - 6 } & C & A & B & A1 & A2 \\
\hline the thickness of the folds on the abdomen $(\mathrm{mm})$ & 0.34 & -0.31 & 0.44 & -0.23 & -0.30 \\
\hline the thickness of the folds on the side $(\mathrm{mm})$ & 0.23 & 0.16 & 0.17 & 0.01 & 0.19 \\
\hline the thickness of the folds on the thigh $(\mathrm{mm})$ & 0.28 & -0.11 & 0.28 & -0.32 & 0.04 \\
\hline the thickness of the folds on the crus $(\mathrm{mm})$ & 0.46 & -0.16 & 0.49 & -0.37 & -0.01 \\
\hline
\end{tabular}

Notes: here and in the future the corresponding direct and inverse correlations of average force and strong are allocated by corresponding colors; C - duration of the rheographic wave (s); A - time of the ascending part of the thigh rheovasogram (s); B - time of the descending part of the rheovasogram (s); A1 - time of rapid blood supply of the rheovasogram (s); A2 - time of slow blood supply of the rheovasogram (s).

Table 2. Values of correlation coefficients ( $r$ ) of time indices of rheovasogram of a thigh with anthropometric sizes at ectomorphs young women volleyball players.

\begin{tabular}{|c|c|c|c|c|c|}
\hline \multirow{2}{*}{ Anthropometric indicators } & \multicolumn{5}{|c|}{ Rheovasographic indicators } \\
\hline & C & $A$ & B & A1 & $\mathrm{A} 2$ \\
\hline body weight (kg) & 0.45 & 0.31 & 0.34 & 0.18 & 0.13 \\
\hline body length $(\mathrm{cm})$ & 0.28 & 0.17 & 0.25 & 0.11 & 0.09 \\
\hline body surface area $\left(\mathrm{m}^{2}\right)$ & 0.39 & 0.28 & 0.30 & 0.15 & 0.14 \\
\hline height of the suprathoracic point $(\mathrm{cm})$ & 0.24 & 0.14 & 0.20 & 0.19 & 0.06 \\
\hline pubic point height $(\mathrm{cm})$ & 0.29 & 0.33 & 0.23 & 0.19 & 0.18 \\
\hline height of the acromial point $(\mathrm{cm})$ & 0.09 & 0.15 & 0.05 & 0.10 & 0.09 \\
\hline finger point height $(\mathrm{cm})$ & 0.01 & 0.23 & -0.06 & 0.20 & 0.17 \\
\hline acetabulum point height $(\mathrm{cm})$ & 0.42 & 0.33 & 0.36 & 0.19 & 0.20 \\
\hline the width of the distal epiphysis of the shoulder $(\mathrm{cm})$ & 0.31 & -0.07 & 0.34 & 0.06 & -0.13 \\
\hline the width of the epiphysis forearm $(\mathrm{cm})$ & 0.23 & 0.17 & 0.17 & 0.12 & 0.10 \\
\hline the width of the distal epiphysis of the thigh $(\mathrm{cm})$ & 0.18 & -0.26 & 0.26 & -0.15 & -0.20 \\
\hline the width of the distal epiphysis of the crus $(\mathrm{cm})$ & 0.37 & 0.03 & 0.33 & -0.09 & 0.09 \\
\hline shoulder girth in a tense state $(\mathrm{cm})$ & 0.24 & 0.28 & 0.14 & 0.16 & 0.10 \\
\hline shoulder girth in a relaxed state $(\mathrm{cm})$ & 0.32 & 0.22 & 0.24 & 0.06 & 0.11 \\
\hline forearm girth at the top $(\mathrm{cm})$ & 0.48 & 0.28 & 0.40 & -0.05 & 0.18 \\
\hline forearm girth at the bottom $(\mathrm{cm})$ & 0.10 & 0.13 & 0.07 & 0.08 & 0.00 \\
\hline thigh girth $(\mathrm{cm})$ & 0.37 & 0.37 & 0.28 & 0.07 & 0.26 \\
\hline crus girth at the top $(\mathrm{cm})$ & 0.59 & 0.27 & 0.45 & 0.01 & 0.12 \\
\hline crus girth at the bottom $(\mathrm{cm})$ & 0.16 & 0.08 & 0.12 & -0.26 & 0.14 \\
\hline neck circumference $(\mathrm{cm})$ & 0.35 & 0.23 & 0.29 & -0.09 & 0.20 \\
\hline waist circumference (cm) & 0.30 & 0.32 & 0.21 & 0.06 & 0.28 \\
\hline thighs girth $(\mathrm{cm})$ & 0.21 & 0.49 & 0.08 & 0.38 & 0.21 \\
\hline hand girth $(\mathrm{cm})$ & 0.23 & 0.08 & 0.14 & 0.04 & -0.05 \\
\hline foot girth $(\mathrm{cm})$ & 0.01 & -0.30 & 0.08 & -0.48 & -0.11 \\
\hline chest girth on inhalation $(\mathrm{cm})$ & 0.25 & 0.23 & 0.20 & -0.01 & 0.11 \\
\hline chest girth on exhalation (cm) & 0.27 & 0.17 & 0.22 & -0.01 & 0.12 \\
\hline chest girth at rest $(\mathrm{cm})$ & 0.26 & 0.23 & 0.19 & 0.02 & 0.10 \\
\hline transverse mid-thoracic diameter $(\mathrm{cm})$ & 0.15 & 0.09 & 0.06 & 0.14 & -0.12 \\
\hline transverse lower thoracic diameter $(\mathrm{cm})$ & -0.08 & 0.02 & -0.09 & -0.34 & 0.24 \\
\hline sagittal mid-thoracic diameter $(\mathrm{cm})$ & 0.39 & -0.01 & 0.40 & 0.28 & -0.25 \\
\hline acromial diameter (cm) & 0.20 & 0.10 & 0.19 & 0.26 & -0.13 \\
\hline
\end{tabular}


Table 2. (continuation)

\begin{tabular}{|l|c|c|c|c|c|}
\hline \multicolumn{2}{|c|}{ Anthropometric indicators } & \multicolumn{4}{|c|}{ Rheovasographic indicators } \\
\cline { 2 - 5 } & C & A & B & A1 & A2 \\
\hline intercristal distance $(\mathrm{cm})$ & 0.22 & 0.43 & 0.09 & 0.43 & 0.12 \\
\hline interspinous distance $(\mathrm{cm})$ & 0.05 & 0.45 & -0.07 & 0.45 & 0.14 \\
\hline intertrochanteric distance $(\mathrm{cm})$ & 0.24 & 0.35 & 0.14 & 0.30 & 0.10 \\
\hline external conjugate $(\mathrm{cm})$ & 0.42 & 0.30 & 0.27 & -0.07 & 0.42 \\
\hline the thickness of the folds on the back of the shoulder $(\mathrm{mm})$ & -0.16 & -0.39 & -0.03 & -0.12 & -0.22 \\
\hline the thickness of the folds on the front surface of the shoulder $(\mathrm{mm})$ & 0.28 & -0.11 & 0.24 & -0.03 & -0.09 \\
\hline the thickness of the folds on the forearm $(\mathrm{mm})$ & 0.31 & -0.23 & 0.37 & -0.13 & -0.19 \\
\hline the thickness of the folds under the shoulder blade $(\mathrm{mm})$ & 0.15 & -0.36 & 0.21 & -0.11 & -0.31 \\
\hline the thickness of the folds on the chest $(\mathrm{mm})$ & 0.04 & -0.40 & 0.17 & -0.20 & -0.34 \\
\hline the thickness of the folds on the abdomen $(\mathrm{mm})$ & 0.00 & -0.49 & 0.12 & -0.10 & -0.48 \\
\hline the thickness of the folds on the side $(\mathrm{mm})$ & -0.01 & -0.48 & 0.13 & -0.27 & -0.28 \\
\hline the thickness of the folds on the thigh $(\mathrm{mm})$ & 0.08 & -0.29 & 0.20 & -0.25 & -0.11 \\
\hline the thickness of the folds on the crus $(\mathrm{mm})$ & 0.12 & -0.47 & 0.26 & -0.09 & -0.43 \\
\hline
\end{tabular}

Table 3. Values of correlation coefficients $(r)$ of time indices of rheovasogram of a thigh with anthropometric sizes at ecto-mesomorphs young women volleyball players.

\begin{tabular}{|c|c|c|c|c|c|}
\hline \multirow{2}{*}{ Anthropometric indicators } & \multicolumn{5}{|c|}{ Rheovasographic indicators } \\
\hline & C & A & B & A1 & $\mathrm{A} 2$ \\
\hline body weight $(\mathrm{kg})$ & 0.23 & 0.35 & 0.19 & 0.47 & -0.07 \\
\hline body length $(\mathrm{cm})$ & 0.17 & 0.28 & 0.15 & 0.41 & -0.10 \\
\hline body surface area $\left(\mathrm{m}^{2}\right)$ & 0.19 & 0.32 & 0.16 & 0.43 & -0.09 \\
\hline height of the suprathoracic point $(\mathrm{cm})$ & 0.07 & 0.24 & 0.05 & 0.36 & -0.10 \\
\hline pubic point height $(\mathrm{cm})$ & 0.12 & 0.14 & 0.12 & 0.25 & -0.11 \\
\hline height of the acromial point $(\mathrm{cm})$ & 0.13 & 0.29 & 0.10 & 0.41 & -0.07 \\
\hline finger point height $(\mathrm{cm})$ & 0.13 & 0.12 & 0.13 & 0.28 & -0.17 \\
\hline acetabulum point height $(\mathrm{cm})$ & 0.14 & 0.23 & 0.12 & 0.32 & -0.05 \\
\hline the width of the distal epiphysis of the shoulder $(\mathrm{cm})$ & -0.14 & -0.37 & -0.10 & -0.54 & -0.04 \\
\hline the width of the epiphysis forearm $(\mathrm{cm})$ & 0.22 & -0.33 & 0.31 & -0.08 & -0.40 \\
\hline the width of the distal epiphysis of the thigh $(\mathrm{cm})$ & -0.20 & -0.39 & -0.11 & -0.38 & -0.31 \\
\hline the width of the distal epiphysis of the crus $(\mathrm{cm})$ & 0.19 & 0.03 & 0.21 & 0.07 & -0.08 \\
\hline shoulder girth in a tense state $(\mathrm{cm})$ & -0.01 & 0.18 & -0.03 & 0.43 & -0.20 \\
\hline shoulder girth in a relaxed state $(\mathrm{cm})$ & -0.07 & 0.02 & -0.06 & 0.22 & -0.27 \\
\hline forearm girth at the top $(\mathrm{cm})$ & 0.00 & -0.09 & 0.03 & 0.35 & -0.44 \\
\hline forearm girth at the bottom $(\mathrm{cm})$ & -0.02 & -0.32 & 0.04 & -0.05 & -0.40 \\
\hline thigh girth $(\mathrm{cm})$ & 0.22 & 0.26 & 0.20 & 0.36 & -0.11 \\
\hline crus girth at the top $(\mathrm{cm})$ & 0.16 & 0.46 & 0.09 & 0.56 & 0.02 \\
\hline crus girth at the bottom $(\mathrm{cm})$ & 0.40 & 0.44 & 0.31 & 0.44 & 0.12 \\
\hline neck circumference $(\mathrm{cm})$ & 0.20 & -0.29 & 0.30 & -0.02 & -0.48 \\
\hline waist circumference $(\mathrm{cm})$ & 0.12 & 0.14 & 0.12 & 0.21 & -0.10 \\
\hline thighs girth $(\mathrm{cm})$ & 0.22 & 0.37 & 0.17 & 0.37 & 0.04 \\
\hline hand girth $(\mathrm{cm})$ & 0.07 & -0.18 & 0.10 & 0.03 & -0.28 \\
\hline foot girth (cm) & 0.21 & -0.07 & 0.24 & -0.14 & -0.10 \\
\hline
\end{tabular}


Correlations of time indicators of thigh rheogram with anthropometric dimensions in volleyball players...

Table 3. (continuation)

\begin{tabular}{|c|c|c|c|c|c|}
\hline \multirow{2}{*}{ Anthropometric indicators } & \multicolumn{5}{|c|}{ Rheovasographic indicators } \\
\hline & $\mathrm{C}$ & A & $B$ & $\mathrm{~A} 1$ & A2 \\
\hline chest girth on inhalation (cm) & 0.13 & 0.31 & 0.10 & 0.50 & -0.13 \\
\hline chest girth on exhalation $(\mathrm{cm})$ & 0.07 & 0.25 & 0.04 & 0.41 & -0.11 \\
\hline chest girth at rest $(\mathrm{cm})$ & 0.06 & 0.25 & 0.04 & 0.41 & -0.15 \\
\hline transverse mid-thoracic diameter $(\mathrm{cm})$ & 0.37 & 0.17 & 0.35 & 0.17 & 0.00 \\
\hline transverse lower thoracic diameter $(\mathrm{cm})$ & 0.09 & -0.16 & 0.13 & -0.25 & -0.16 \\
\hline sagittal mid-thoracic diameter $(\mathrm{cm})$ & 0.29 & 0.13 & 0.28 & 0.18 & -0.18 \\
\hline acromial diameter $(\mathrm{cm})$ & 0.28 & -0.02 & 0.31 & 0.11 & -0.21 \\
\hline intercristal distance (cm) & 0.35 & 0.24 & 0.31 & 0.28 & -0.03 \\
\hline interspinous distance $(\mathrm{cm})$ & 0.07 & 0.31 & 0.02 & 0.30 & 0.04 \\
\hline intertrochanteric distance $(\mathrm{cm})$ & 0.36 & 0.24 & 0.34 & 0.34 & -0.07 \\
\hline external conjugate $(\mathrm{cm})$ & 0.12 & 0.05 & 0.11 & 0.22 & -0.27 \\
\hline the thickness of the folds on the back of the shoulder $(\mathrm{mm})$ & -0.10 & -0.28 & -0.09 & -0.07 & -0.16 \\
\hline the thickness of the folds on the front surface of the shoulder $(\mathrm{mm})$ & -0.10 & -0.01 & -0.11 & -0.07 & 0.14 \\
\hline the thickness of the folds on the forearm $(\mathrm{mm})$ & 0.02 & -0.18 & 0.06 & -0.21 & 0.03 \\
\hline the thickness of the folds under the shoulder blade $(\mathrm{mm})$ & -0.08 & -0.02 & -0.10 & 0.20 & -0.12 \\
\hline the thickness of the folds on the chest $(\mathrm{mm})$ & -0.36 & -0.34 & -0.31 & -0.37 & -0.03 \\
\hline the thickness of the folds on the abdomen (mm) & -0.46 & -0.42 & -0.38 & -0.60 & -0.01 \\
\hline the thickness of the folds on the side $(\mathrm{mm})$ & -0.27 & -0.54 & -0.17 & -0.54 & -0.19 \\
\hline the thickness of the folds on the thigh $(\mathrm{mm})$ & -0.17 & -0.23 & -0.12 & -0.08 & -0.26 \\
\hline the thickness of the folds on the crus (mm) & -0.07 & -0.30 & 0.00 & -0.14 & -0.29 \\
\hline
\end{tabular}

Table 4. Values of correlation coefficients ( $r$ ) of temporal indices of rheovasogram of a thigh with anthropometric sizes at young women volleyball players with average intermediate somatotype.

\begin{tabular}{|c|c|c|c|c|c|}
\hline \multirow{2}{*}{ Anthropometric indicators } & \multicolumn{5}{|c|}{ Rheovasographic indicators } \\
\hline & C & A & B & A1 & $\mathrm{A} 2$ \\
\hline body weight (kg) & 0.46 & -0.20 & 0.45 & 0.20 & -0.28 \\
\hline body length $(\mathrm{cm})$ & 0.32 & -0.07 & 0.27 & 0.33 & -0.17 \\
\hline body surface area $\left(\mathrm{m}^{2}\right)$ & 0.40 & -0.19 & 0.39 & 0.25 & -0.28 \\
\hline height of the suprathoracic point $(\mathrm{cm})$ & 0.38 & 0.06 & 0.28 & 0.46 & -0.06 \\
\hline pubic point height $(\mathrm{cm})$ & 0.30 & -0.15 & 0.27 & 0.17 & -0.17 \\
\hline height of the acromial point $(\mathrm{cm})$ & 0.42 & 0.01 & 0.32 & 0.37 & -0.08 \\
\hline finger point height $(\mathrm{cm})$ & 0.14 & -0.22 & 0.11 & 0.17 & -0.27 \\
\hline acetabulum point height $(\mathrm{cm})$ & 0.44 & 0.20 & 0.33 & 0.49 & 0.11 \\
\hline the width of the distal epiphysis of the shoulder $(\mathrm{cm})$ & 0.40 & 0.31 & 0.31 & 0.39 & 0.21 \\
\hline the width of the epiphysis forearm $(\mathrm{cm})$ & 0.16 & -0.17 & 0.10 & 0.05 & -0.17 \\
\hline the width of the distal epiphysis of the thigh $(\mathrm{cm})$ & 0.12 & 0.08 & 0.05 & 0.07 & 0.15 \\
\hline the width of the distal epiphysis of the crus $(\mathrm{cm})$ & 0.06 & 0.08 & -0.05 & 0.20 & 0.07 \\
\hline shoulder girth in a tense state $(\mathrm{cm})$ & 0.31 & -0.32 & 0.37 & -0.05 & -0.38 \\
\hline shoulder girth in a relaxed state $(\mathrm{cm})$ & 0.35 & -0.35 & 0.41 & -0.07 & -0.39 \\
\hline forearm girth at the top $(\mathrm{cm})$ & 0.35 & -0.33 & 0.37 & -0.09 & -0.35 \\
\hline forearm girth at the bottom $(\mathrm{cm})$ & -0.10 & -0.36 & -0.11 & -0.08 & -0.35 \\
\hline thigh girth $(\mathrm{cm})$ & 0.38 & -0.38 & 0.46 & 0.02 & -0.44 \\
\hline
\end{tabular}


Table 4. (continuation)

\begin{tabular}{|c|c|c|c|c|c|}
\hline \multirow{2}{*}{ Anthropometric indicators } & \multicolumn{5}{|c|}{ Rheovasographic indicators } \\
\hline & C & $A$ & $B$ & A1 & $\mathrm{A} 2$ \\
\hline crus girth at the top $(\mathrm{cm})$ & 0.21 & -0.49 & 0.30 & -0.19 & -0.52 \\
\hline crus girth at the bottom $(\mathrm{cm})$ & 0.35 & -0.40 & 0.42 & 0.01 & -0.44 \\
\hline neck circumference $(\mathrm{cm})$ & -0.02 & -0.27 & 0.00 & 0.01 & -0.19 \\
\hline waist circumference $(\mathrm{cm})$ & 0.43 & -0.20 & 0.44 & 0.12 & -0.21 \\
\hline thighs girth $(\mathrm{cm})$ & 0.25 & -0.42 & 0.34 & -0.11 & -0.47 \\
\hline hand girth $(\mathrm{cm})$ & 0.20 & -0.35 & 0.25 & -0.02 & -0.40 \\
\hline foot girth (cm) & 0.25 & -0.35 & 0.31 & -0.03 & -0.33 \\
\hline chest girth on inhalation $(\mathrm{cm})$ & 0.62 & 0.12 & 0.55 & 0.24 & 0.06 \\
\hline chest girth on exhalation $(\mathrm{cm})$ & 0.51 & -0.01 & 0.48 & 0.11 & -0.06 \\
\hline chest girth at rest $(\mathrm{cm})$ & 0.65 & 0.11 & 0.59 & 0.17 & 0.05 \\
\hline transverse mid-thoracic diameter $(\mathrm{cm})$ & 0.30 & -0.12 & 0.25 & 0.33 & -0.18 \\
\hline transverse lower thoracic diameter $(\mathrm{cm})$ & 0.27 & 0.20 & 0.15 & 0.57 & 0.12 \\
\hline sagittal mid-thoracic diameter $(\mathrm{cm})$ & 0.52 & -0.12 & 0.53 & -0.13 & -0.06 \\
\hline acromial diameter $(\mathrm{cm})$ & 0.35 & -0.27 & 0.42 & -0.15 & -0.23 \\
\hline intercristal distance $(\mathrm{cm})$ & 0.05 & 0.04 & 0.02 & 0.42 & -0.07 \\
\hline interspinous distance $(\mathrm{cm})$ & 0.16 & 0.13 & 0.08 & 0.60 & -0.01 \\
\hline intertrochanteric distance $(\mathrm{cm})$ & 0.29 & -0.27 & 0.34 & 0.20 & -0.33 \\
\hline external conjugate $(\mathrm{cm})$ & 0.33 & -0.20 & 0.37 & 0.23 & -0.32 \\
\hline the thickness of the folds on the back of the shoulder $(\mathrm{mm})$ & -0.11 & 0.41 & -0.16 & -0.01 & 0.45 \\
\hline the thickness of the folds on the front surface of the shoulder $(\mathrm{mm})$ & -0.13 & -0.45 & 0.02 & -0.54 & -0.39 \\
\hline the thickness of the folds on the forearm $(\mathrm{mm})$ & -0.22 & -0.48 & -0.05 & -0.50 & -0.45 \\
\hline the thickness of the folds under the shoulder blade $(\mathrm{mm})$ & -0.11 & 0.00 & -0.13 & -0.24 & 0.09 \\
\hline the thickness of the folds on the chest (mm) & -0.15 & -0.63 & 0.03 & -0.71 & -0.48 \\
\hline the thickness of the folds on the abdomen (mm) & -0.01 & 0.48 & -0.17 & 0.03 & 0.60 \\
\hline the thickness of the folds on the side (mm) & 0.17 & 0.51 & -0.04 & 0.32 & 0.58 \\
\hline the thickness of the folds on the thigh (mm) & -0.02 & 0.50 & -0.13 & -0.04 & 0.54 \\
\hline the thickness of the folds on the crus (mm) & -0.29 & 0.05 & -0.33 & -0.52 & 0.20 \\
\hline
\end{tabular}

significantly correlated with the following anthropometric dimensions: the width of the distal epiphysis of the forearm, neck and forearm girth in the upper and lower parts.

We found that in volleyball players of the middle intermediate somatotype, the duration of the rheographic wave on the thigh had significant connections with body weight, acetabular point height, waist circumference and all chest sizes, sagittal mid-thoracic diameter (Table 4).

The time of the ascending part of the rheovasogram of the thigh had significant correlations with the girth of the crus and thighs, the thickness of the skin and fat folds on the shoulders, forearms, chest, abdomen, thighs and sides. The time of the descending part of the rheovasogram significantly correlated with body weight, thigh girt, waist girth, chest at inhalation, exhalation and at rest, acromial and sagittal mid-thoracic diameters. The time of rapid blood supply to the femoral vessels had statistically significant correlations with the height of the suprathoracic and acetabular points, transverse lower thoracic diameter, intercristal distance of the pelvis, the thickness of the folds on the front surface of the shoulder, forearm, chest, crus. The time of slow blood supply was significantly correlated with the girth of the thigh, crus in the upper and lower parts, thighs, the thickness of the folds on the back of the shoulder, forearm, chest, abdomen, sides and thighs (see Table 4).

\section{Discussion}

A number of works have been devoted to the study of the relationships of individual indicators of the cardiovascular system with anthropo-somatotypological parameters in volleyball players. In particular, correlations were found between the indicators of central hemodynamics and constitutional body parameters in groups of highly qualified male volleyball players [7] and females [20, 27]. It 
was found that the parameters of peripheral hemodynamics in athletes of this sport were associated with certain parameters of external body structure [11], but in comparison with wrestlers and athletes in volleyball players on the thigh was found the lowest number of rheovasographic parameters that significantly correlated with the parameters of external body structure [12].

Scientists have proved that the representatives of individual somatotypes differ not only in the external structure of the body [19], but also in the morpho-functional features of the cardiovascular system $[5,24,26]$. Therefore, the constitutional approach in determining the features of the correlations between the indicators of the external structure of the body and hemodynamic parameters has a clear practical direction [21, 25]. Our study shows that highly skilled volleyball players belonging to different constitutional groups differ in the strength and number of reliable relationships between temporal rheovasographic parameters of the thigh and anthropometric body size. Thus, in mesomorphic volleyball players it was found that the duration of the rheographic wave had the lowest number of reliable correlations, only $4.5 \%$ of all possible. The time of the ascending part of the femoral rheovasogram significantly correlated with $25.0 \%$ of the anthropometric dimensions we determined. It is noteworthy that all correlations are straight, medium strength. Features of the established connections testify that at increase in width of distal epiphyses of a thigh and a crus and circumferential sizes of a body and diameters of a trunk at volleyball players of mesomorphic somatotype the speed of regional bloodgroove will slow down, because of a tone of resistance vessels (arterioles and capillaries) [17]. The time of the descending part of the rheovasogram of the thigh, which depends on the heart rate, was significantly correlated only with the thickness of 3 skin and fat folds $(6.8 \%$ of all body sizes). The time of rapid blood supply was significantly correlated with only $11.4 \%$ of anthropometric sizes, with correlations of medium strength with chest girths, strong straight with mid-thoracic diameter, inverse width shoulder width and thickness of folds on the forearm. The volleyball players of mesomorphic somatotype had the largest number of reliable $(29.5 \%)$ and strong correlations $(6.8 \%$ of them were strong) of time of slow blood supply of the thigh rheovasogram, which depends on the tone of small and medium diameter arteries [17]. Therefore, with increasing the longitudinal size of the body, the width of the distal epiphyses of the thigh and crus and the circumferential size of the neck and limb segments will increase the time of slow blood supply.

In the general group of male volleyball players, as in our study for mesomorphic somatotype young women volleyball players, of all time parameters of the thigh rheovasogram, the most numerous correlations were found for the time of the ascending part of the rheogram and slow blood supply, which were interrelated with longitudinal and circumferential dimensions limbs and width of the distal epiphyses of the extremities [12]. In mesomorphic volleyball players, the time of the ascending part of the rheogram and the time of slow blood supply of thigh vessels had the greatest number of reliable correlations [14].

We found that in ectomorph volleyball players the number of significant correlations and their strength $(r=0.38-0.48)$ were smaller compared to mesomorphic somatotype athletes. In particular, the duration of the rheographic wave on the thigh was correlated with $11.4 \%$ of anthropometric indicators, the time of the ascending part of the rheovasogram - with $18.2 \%$, the time of the descending part - with $6.8 \%$, the time of rapid blood supply - with $6.8 \%$, the time of slow blood supply - with $6.8 \%$ of external body size. The established relationships indicate that in volleyball players of ectomorphic somatotype with increasing diameters of the pelvis and girth of the forearm, crus, thighs, there will be an elongation of the time parameters of the rheovasogram of the thigh. In practically healthy girls of Podillia, who did not play sports and belonged to the ectomorphic somatotype, the highest number of significant inverse correlations was found between temporal rheovasographic parameters on the thigh and transverse body size [21], which, in our opinion, is evidence that they as the body diameters increase, the time values will be smaller.

In volleyball players with ecto-mesomorphic body type, a large number of reliable inverse correlations were found between the time indicators of peripheral hemodynamics and anthropometric body size. It is noteworthy that the thickness of the skin and fat folds is inversely proportional to most of the time parameters of the thigh rheovasogram, except for the time of slow blood supply. The duration of the rheographic wave significantly correlated with $6.8 \%$ of anthropometric indicators, the time of the ascending part of the rheovasogram - with $15.9 \%$, the time of the descending part - with $2.3 \%$, the time of rapid blood filling - with $38.6 \%$ (direct correlations predominate), the time of slow blood filling - with $9.1 \%$ of external size body (all correlations are inverse). Thus, in volleyball players with this body type, the most numerous and strongest connection with anthropometric body size was the time of rapid blood supply, which depends on the tone of the vascular wall of large arteries and is determined by the contractile function of the myocardium [17]. Analysis of the identified reliable relationships suggests that with increasing total body size, acromial point height, circumferential size of the shoulder, thigh, crus, thighs, chest and reducing subcutaneous fat and the width of the distal epiphysis of the thigh in volleyball players with ecto-mesomorphic somatotype will increase the time of rapid blood supply. It has previously been found [13] that in adolescent male volleyball players of the ectomesomorphic somatotype will increase the elasticity of the wall of the thigh arteries with increasing body weight, especially its muscle and fat components, and this, in turn, will lead to higher time of rapid blood supply.

In highly qualified young women volleyball players of 
medium intermediate somatotype, compared with athletes of other constitutional types, the duration of the rheographic wave correlated with the largest number of body sizes $(15.9 \%)$, all correlations are straight, medium strength $(r=0.43-0.52)$ and strong $(r=0.62-0.65)$. It is noteworthy that with increasing body weight, leg length, waist circumference and chest, anterior-posterior mid-thoracic size will increase the duration of the rheographic wave. The time of the ascending part of the thigh rheovasogram in volleyball players of this somatotype correlated with $18.2 \%$ of body size, interesting is the different nature of the relationship between this time rheovasographic index and subcutaneous fat. Thus, with increasing the size of the folds on the thigh, side, abdomen and decrease - on the chest, forearms, shoulders and thighs and crus will increase the tone of small diameter, and hence the time of the ascending part of the rheovasogram $[13,17]$. The time of the descending part of the rheovasogram had straight medium correlation with $18.2 \%$ of anthropometric dimensions, mainly with the circumferential dimensions and width of the shoulders and pelvis. The time of rapid blood supply also had significant correlations with $18.2 \%$ of body size, with the thickness of the folds the correlations were inverse, with longitudinal and transverse dimensions - straight. Among the temporal parameters of the rheovasogram in volleyball players with an average intermediate somatotype, the time of slow blood filling had

\section{References}

[1] Braber, T. L., Mosterd, A., Prakken, N. H., Rienks, R., Nathoe, H. M., Mali, W. P., ... Velthuis, B. K. (2016). Occult coronary artery disease in middle-aged sportsmen with a low cardiovascular risk score: the measuring athlete's risk of cardiovascular events (MARC) study. Eur. J. Prevent. Cardiol., 23, 1677-1684. doi: 10.1177/2047487316651825

[2] Bunak, V. V. (1941). Anthropometry: a practicalcourse. M.: Uchpedgiz.

[3] Carter, J. L., \& Heath, B. H. (1990). Somatotyping - development and applications. Cambridge University Press.

[4] Green, D. J., Spence, A., Rowley, N., Thijssen D. H., \& Naylor, L. H. (2012). Vascular adaptation in athletes: is there an 'athlete's artery'? Exp. Physiol., 97, 295-304. doi: 10.1113/ expphysiol.2011.058826

[5] Kyrychenko, Y. V. (2014). Indicators of electrical activity of the heart in boys and girls athletes and non-athletes with different body types. Reports of Vinnytsia National Medical University, 18(1), 10-14.

[6] Lewandowska, J., Busko, K., Pastuszak, A., \& Boguszewska, K. (2011). Somatotype variables related to muscle torque and power in judaists. J. Hum. Kinet., 30, 21-28. doi: 10.2478/ v10078-011-0069-y

[7] Lezhnyova, Y. V., \& Sarafinuk, L. A. (2012). Correlations of rheocardiographic parameters of central hemodynamics with the indices of physical development of the volleyball players. Reports of Vinnytsia National Medical University, 16(1), 227229.

[8] Liu, J., Lewis, G., \& Evans, L. (2013). Understanding Aggressive Behavior Across the Life Span. Journal of Psychiatric and Mental Health Nursing, 20(2), 156-168. doi: 10.1111/j.13652850.2012.01902.x the most numerous correlations $(22.7 \%)$.

The established features of the relationship between the temporal parameters of peripheral hemodynamics and anthropometric body size in young women volleyball players of different somatotypes will allow to predict morphofunctional changes of the thigh vessels in accordance with changes in body components.

\section{Conclusions}

1. It was found that in mesomorphic young women volleyball players the most numerous correlations with anthropometric dimensions were found for the time of the ascending part of the rheogram and slow blood filling; in ectomorphs - only for the time of the ascending part of the rheovasogram; in ecto-mesomorphs - for the time of rapid blood supply; in volleyball players of medium intermediate somatotype - for the time of slow blood supply.

2. Of the anthropometric body sizes, the most numerous and strongest correlations with the temporal indices of the thigh rheogram in young women volleyball players of different constitutional types had longitudinal body sizes (only direct correlations), width of the distal epiphysis of the thigh and crus (mostly direct correlations), circumferential dimensions of limb segments and chest (mostly direct correlations) and the thickness of skin and fat folds (mostly inverse correlations).

[9] Liu, J., Sui, X., Lavie, C. J., Zhou, H., Park, Y. M., Cai, B., ... Blair, S. N. (2014). Effects of cardiorespiratory fitness on blood pressure trajectory with aging in a cohort of healthy men. $J$. Am. Coll. Cardiol., 64, 1245-1253. doi: 10.1016/ j.jacc.2014.06.1184

[10] McClean, G., Riding, N. R., Ardern, C. L., Farooq, A., Pieles, G. E., \& Watt, V. (2017). Electrical and structural adaptations of the paediatric athlete's heart: a systematic review with metaanalysis. Br. J. Sports Med., 52, 230. doi: 10.1136/bjsports2016-097052

[11] Moroz, V. M., Khapitska, O. P., Lisyuk, S. P., \& Kachan, V. (2016). The relationship reovasographic parameters of the tibia with anthropometric dimensions, components of somatotype and weight of wrestlers, athletes and volleyball players. Bulletin of Problems Biology and Medicine, 4, 2(134), 224-229.

[12] Moroz, V. M., Khapitska, O. P. \& Sarafinyuk, L. A. (2016). The interrelation of rheovasographic parameters of the hip with external indicators of body structure in athletes of different sports. Reports of Morphology, 22(2), 372-379.

[13] Moroz, V. M., Khapitska, O. P., Sarafinyuk, L. A., laremyn, S. Y., \& Androshchuk, O. V. (2019). Correlation of thigh rheovasographic indices with constitutional characteristics in volleyball players of ecto-mesomorphic somatotype. World of Medicine and Biology, 3(69), 122-127. doi: 10.26724/20798334-2019-3-69-122-127

[14] Moroz, V. M., Sarafinyuk, L. A. \& Khapitska O. P. (2016). Correlation of hemodynamic parameters hip with constitutional characteristics of sportsmen with mesomorphic somatotype. Biomedical and Biosocial Anthropology, 27, 112-118.

[15] Myer, G. D., Jayanthi, N., Difiori, J. P., Faigenbaum, A. D., 
Kiefer, A. W., Logerstedt, D., \& Micheli, L. J. (2015). Does Early Sports Specialization Increase Negative Outcomes and Reduce the Opportunity for Success in Young Athletes? Sports Health, 7(5), 437-442. doi: 10.1177/1941738115598747

[16] Raschka, C., \& Aichele, S. K. (2014). Correlations between somatotypes and nutritional intake in sports students. Papers on Anthropology, 23(2), 96-104. doi: 10.12697/ poa.2014.23.2.09

[17] Ronkin, M. A., \& Ivanov, L. B. (1997). Rheography in clinical practice. Moscow: Scientific and Medical Company MBN.

[18] Sabato, T. M., Walch, T. J., \& Caine, D. J. (2016). The elite young athlete: strategies to ensure physical and emotional health. Open Access J. Sports Med., 7, 99-113. doi: 10.2147/ OAJSM.S96821

[19] Sarafyniuk, L. A. Pivtorak, V. I., Khavtur, V. O., Fedoniuk, L. la., \& Khapitska, O. P. (2018). Peculiarities of the chest"s size in female volleyball players of different constitutional types. Biomedical and Biosocial Anthropology, 33, 47-53. doi: 10.31393/bba33-2018-08

[20] Sarafynyuk, L. A., \& Yakusheva, Yu. I. (2015). Correlation indicators of central hemodynamic with anthropometric and somatotypological parameters in young volleyball players. World of Medicine and Biology, 3(51), 79-82.

[21] Serheta, I. V., Vysochanskiy, O. V., \& Cherepaha, O. L. (2015). Features of correlation indicators rheovasography of thigh and shin with anthropometric body parameters a in healthy girls with different somatotypes. World of Medicine and Biology, 3(51), 86-89.

[22] Sharma, S., Merghani, A., \& Mont, L. (2015). Exercise and the heart: the good, the bad, and the ugly. Eur. Heart J., 36, 14451453. doi: 10.1093/eurheartj/ehv090

[23] Tkachuk, M. G., Dusenova, A. A., Gruzdeva, N. S., \& Sobolev, A. A. (2012). Morphological criteria of sports selection in martial. Morphology, 3, 156.

[24] Vadzyuk, S. N., Gunas, I. V., \& Cvintarnii, A. V. (2014). Features of the temporal and amplitude parameters of reovazography hip in healthy boys and girls of different somatotypes. Ukrainian Morphological Almanac, 12(2), 92-94.

[25] Vysochanskiy, O. V. (2015). Differences of correlation indices of rheovasography of hip and shin with anthropo-somatometric parameters in healthy podillya boys with different somatotypes. World of Medicine and Biology, 3(51), 15-19.

[26] Yakusheva, Yu. I. (2015). Indicators of central hemodynamics in volleyball players with different body types. Bulletin of Problems Biology and Medicine, 3(123), 344-347.

[27] Yakusheva, Yu. I., Sarafynyuk, L. A., \& Kyrychenko, Yu. V. (2015). Interralations of reocardiographic parametres of central hemodinamics with constitutional indicators by volleyball players of difderent positions. World of Medicine and Biology, 4(53), 96-102.

\section{КОРЕЛЯЦІЇ ЧАСОВИХ ПОКАЗНИКІВ РЕОГРАМИ СТЕГНА З АНТРОПОМЕТРИЧНИМИ РОЗМІРАМИ У ВОЛЕЙБОЛІСТОК РІЗНИХ СОМАТОТИПІВ \\ Хавтур В.О., Федонюк Л.Я, Сарафинюк Л.А., Шаповал О.М., Смолко Н.М.}

Конституціональні особливості організму є суттєвим важелем спортивної результативності, тому що впливають на загальну та спеціальну фізичну працездатність, аеробну продуктивність і показники ефективності роботи систем енергозабезпечення, зокрема, на показники центральної та периферичної гемодинаміки. Мета роботи - встановити особливості зв'язків між часовими параметрами реовазограми стегна та антропометричними показниками у висококваліфікованих волейболісток юнацького віку, які належать до різних конституціональних типів. Проведене антропосоматотипологічне дослідження 113 волейболісток високого рівня спортивної майстерності юнацького віку (від 16 до 20 років). Антропометричне дослідження проводили за методом В.В. Бунака (1941), соматотипологічне - за розрахунковою модифікацією методу Hеath-Carter (1990). За результатами соматотипування встановили, що 29 волейболісток належали до мезоморфного типу конституції, до ектоморфного - 26 волейболісток, до екто-мезоморфів - 27 волейболісток, до середнього проміжного типу - 26 волейболісток, до ендо-мезоморфів - лише 5 осіб. Реовазографічні параметри стегна визначали за допомогою тетраполярної реокардіографії на комп'ютерному діагностичному комплексі. Оцінку часових реовазограффічних параметрів проведено за методикою Ронкіна та Іванова [1997]. Аналіз отриманих результатів проведений у ліцензійній програмі "Statistica 5.5" із використанням кореляційного аналізу за Спірменом. Нами встановлено, що у волейболісток-мезоморфрів із показниками зовнішньої будови тіла часові параметри реовазограми стегна мали нечисельні достовірні переважно середньої сили, прямі кореляції, за винятком часу висхідної частини реограми та повільного кровонаповнення. У волейболісток ектоморфного соматотипу встановлені взаємозв'язки свідчать про те, що при збільщенні діаметрів таза та обхватних розмірів передпліччя, гомілки, стегон буде спостерігатися подовження часових параметрів реовазограми стегна. У волейболісток з екто-мезоморфним соматотипом виявлено достатньо велику кількість достовірних зворотних кореляцій, товщина шкірно-жирових складок обернено пропорційно взаємопов'язана з більшістю часових параметрів реовазограми стегна, за винятком часу повільного кровонаповнення. У волейболісток середнього проміжного соматотипу, порівняно з іншими групами спостереження, виявлені найчисельніші зв'язки між антропометричними розмірами та часовими показниками реовазограми.

Ключові слова: кореляція, часові показники реовазограми стегна, антропометрія, соматотип, волейболістки.

\section{КОРРЕЛЯЦИИ ВРЕМЕННЫХ ПОКАЗАТЕЛЕЙ РЕОГРАММЫ БЕДРА С АНТРОПОМЕТРИЧЕСКИМИ РАЗМЕРАМИ У ВОЛЕЙБОЛИСТОК РАЗЛИЧНЫХ СОМАТОТИПОВ \\ Хавтур В.О., Федонюк Л.Я, Сарафинюк Л.А., Шаповал Е.Н., Смолко Н.Н.}

Конституциональные особенности организма являются существенным рычагом спортивной результативности, так как влияют на общую и специальную физическую работоспособность, аэробную производительность и показатели эффективности работы систем энергообеспечения, в частности, на показатели центральной и периферической гемодинамики. Цель работы - установить особенности связей между временными параметрами реовазограммы бедра и антропометрическими показателями у высококвалифицированных волейболисток юношеского возраста, принадлежащих к разным конституциональным типам. Проведено антропо-соматотипологическое обследование 113 волейболисток высокого уровня спортивного мастерства юношеского возраста (от 16 до 20 лет). Антропометрическое исследование 
проводили по методу В.В. Бунака (1941), соматотипологическое - по расчетной модификации метода Heath-Carter (1990). По результатам соматотипирования установили, что 29 волейболисток принадлежали к мезоморфнному типу конституции, к эктоморфному - 26 волейболисток, к экто-мезоморфному - 27 волейболисток, к среднему промежуточному типу - 26 волейболисток, к эндо-мезоморфному - всего 5. Реовазографические параметры бедра определяли с помощью тетраполярной реокардиографии на компьютерном диагностическом комплексе. Оценку интервальных реовазографических параметров провели по методике Ронкина и Иванова [1997]. Анализ полученных результатов проведен в лицензионной программе "Statistica 5.5" с использованием корреляционного анализа по Спирмену. Нами установлено, что у волейболисток мезоморфов с показателями внешнего строения тела интервальные параметры реовазограмы бедра имели немногочисленные достоверные преимущественно средней силы, прямые корреляции, за исключением времени восходящей части реограммы и медленного кровенаполнения. У волейболисток эктоморфного соматотипа установленные взаимосвязи свидетельствуют о том, что при увеличении диаметров таза и обхватных размеров предплечья, голени, бедер будет наблюдаться удлинение временных параметров реовазограммы бедра. У волейболисток с экто-мезоморфным соматотипом обнаружено достаточно большое количество достоверных обратных корреляций, толщина кожно-жировых складок обратно пропорционально взаимосвязана с большинством временненых параметров реовазограммы бедра, за исключением времени медленного кровенаполнения. У волейболисток среднего промежуточного соматотипа, по сравнению с другими группами наблюдения, обнаружены самые многочисленные связи между антропометрическими размерами и временными показателями реовазограммы.

Ключевые слова: корреляция, временные показатели реовазограммы бедра, антропометрия, соматотип, волейболистки. 